\section{Harrowing story of prejudice and religious blackmail}

\section{PAT CRADDOCK is a broadcaster and media consultant from Aotearoa/ $\mathrm{New}$ Zealand.}

Murder That Wasn't. The Case of George Gwaze, by Felicity Goodyear-Smith. Dunedin: Otago University Press, 2015. 180pp. ISBN 978-1877578-99-1

$\mathrm{T}$ IIS harrowing book is about George Gwaze, an African migrant to New Zealand who was tried twice for the rape and murder of his 10-year-old niece. It is also about prejudice, HIV/ AIDS and our legal and medical processes when trauma is being investigated. One Saturday morning in January 2007, Charlene, the 10-year-old niece of George Gwaze was found in her bed gasping for breath, lying in a pool of diarrhoea and was rushed to hospital. Charlene was diagnosed with aggressive acute sepsis believed to be the result of violent assault and suffocation. She was also HIV positive.

Next morning Charlene was dead. The police began their inquiries. Their job sheet said that Charlene was thought to be the victim of blunt force trauma inside of anal cavity. Brain injury possibly caused by being suffocated'.

One theory, quickly rejected, was that an intruder had broken into the house. The inquiry then focussed on the male members of the family-George Gwaze and his

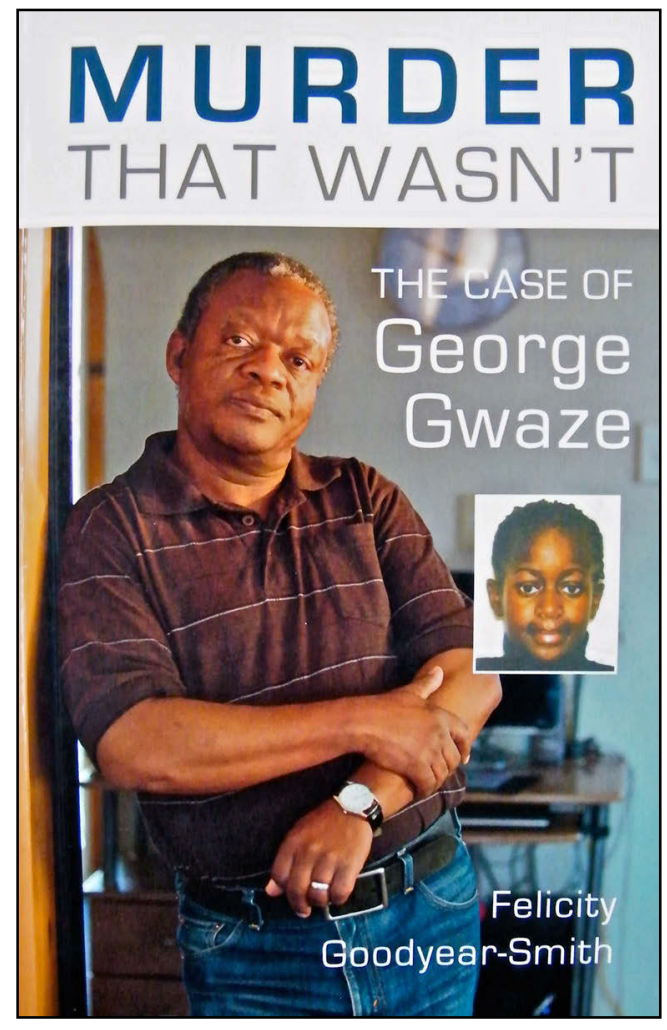

sons, George Junior and Tafadzwa, who were both university students. Nothando, George Gwaze's adult daughter who shared a bedroom with Charlene, was identified by police as a crucial witness.

The police inquiry now moved into a theatre of assumptions to enact a performance of racial prejudice and emotional religious blackmail. A police media release on the day that Charlene died, reported her death as homicide. All the police then had to do was to find the criminal and the Gwaze family were the prime suspects.

Detective Johannsen interviewed George Gwaze, saying that Charlene had internal bruises 'consistent with something being forcibly pushed up her bottom'. She 
had a tear in her anus and was brain dead, which was "consistent with someone trying to suffocate her or holding something over her head'. The detective tried to get a confession out of George Gwaze saying he could decide to '.. cleanse his soul'.

Detective Tinkler was sure that 20-yearold Nothando had the key to resolving the inquiry. She was subjected to a mode of questioning that I hope, has now been abandoned by the police.

Nothando reported that she was interviewed by two detectives who pressured her to confess. They promised to find her a flat away from the family. One detective said he was a Christian, a faith that he shared with Nothando and that if anyone had harmed Charlene it was right to confess. He quoted scriptures saying that she had to choose between God and her family and to tell the truth.

The two Georges, father and son, received their share of prejudicial comment from the police. Detective Johannsen interviewed George, saying that 'AIDS is prevalent in up to 80 pecent of the adult population in Africa' and that having anal sex with a virgin would drive AIDs away. Neither father nor son had AIDS, so the suggestion that either would rape Charlene to cure themselves of AIDS was illogical. Furthermore. George Gwaze vehemently denied that anal sex was acceptable in Zimbabwe as it was regarded as 'taboo'.

Enter Felicity Goodyear-Smith, a forensic physician and the author of this book. Her initial impression was that the physical evidence against George Gwaze was overwhelming, as Charlene had tears in her hymen and rectum, there was sperm in her underwear and she had collapsed from suffocation. However, her closer reading of the file showed much clinical information was missing and she set out to find it.

Her draft report looked at the arguments for and against sepsis and suffocation. This was a critical analysis. GoodyearSmith doubted the initial medical findings, as it appeared to her that the 10-year old girl could have died from the side effects of the HIV virus. Charlene had contracted HIV from her parents in Zimbabwe. They were dead. Tests showed that neither George or his son were HIV positive.

The case came to court. The sperm on the Charlene's underpants might have come from the regular laundering of the family adult and child clothing. Professor Rode, a South African specialist who was unable to attend the trial, said that he had seen a number of children between 8-10 years with congenital HIV who suddenly became sick and died. The jury took less than five hours to acquit George Gwaze of murder and sexual violation.

A dissatisfied Crown appealed and won by arguing that the evidence from Professor Rode was hearsay and inadmissible. George Gwaze was to become the first person in New Zealand to be found innocent of murder and then tried again on the same evidence.

In the first trial, there were no witnesses for the defence, no New Zealand medical experts available and no legal aid to bring in overseas experts. The second trial was different. Expert witnesses spoke for both the Crown and the defence.

Charlene was already dying when the medical staff first saw her and they did all 
they could to help. However, the possibility that the tear in her anus might not have been caused by trauma was excluded from expert evidence given by the Crown, despite the fact that the information had been on hand. It became clear that Charlene had HIV from birth and this had wrecked her body. Inquiries showed she had frequently been sick, often had diarrhoea and missed school.

George Gwaze was acquitted for the second time. But there can be no simple acquittal for the assumptions of the medical, police and legal staff who worked on this case. As this book shows, there was tunnel vision from both medical and police staff. Was there also racism in the inquiry? It appears so and it is mentioned several times in the book. The police acted as if the family were ignorant and uneducated. Nature also interfered with the judicial process as the family was living in Christchurch when the earthquakes happened. The court was destroyed and the office of the Gwaze defence lawyer was damaged.

Murder That Wasn't is an important book, which should be used in workshops and read by police, legal and medical personnel who want to improve the standards of their professions. Journalists need to read this book too, as assumptions can be dangerous for any of us.

A couple of improvements could be made in any reprint, such as providing an appendix giving names and positions of police and medical staff involved, and a medical terminology glossary.

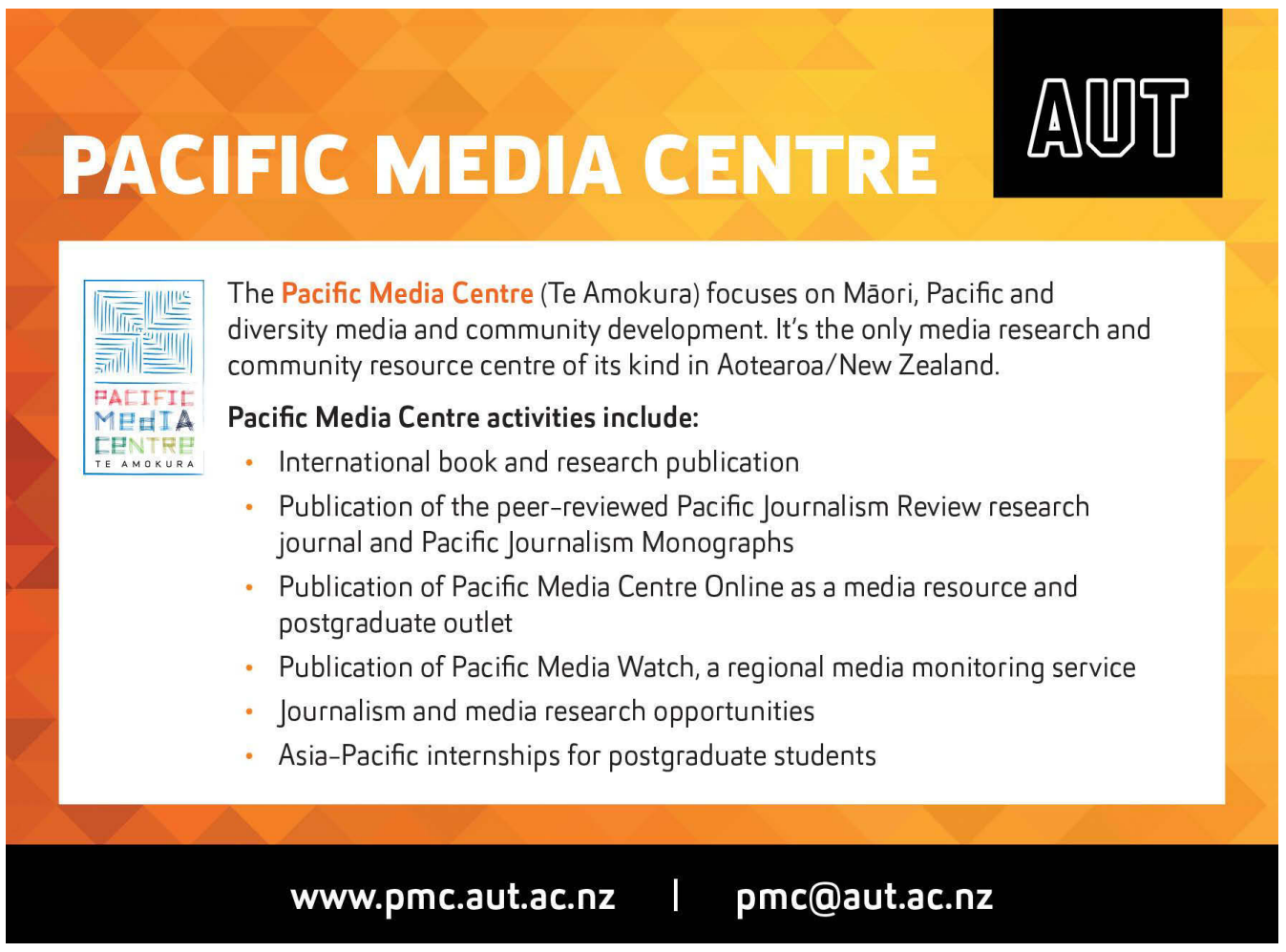

210 PACIFIC JOURNALISM REVIEW 21(1) 2015 